\section{Burden of dengue in the State of Meta, Colombia (2010-2016)}

\section{Carga del dengue en el Estado de Meta, Colombia (2010-2016)}

\section{Carga da dengue no Estado de Meta, Colômbia (2010-2016)}

Adolfo Vásquez-Trujillo 1

Doris Cardona-Arango 1

Angela María Segura-Cardona 1

Gabriel Jaime Parra-Henao 1

\begin{abstract}
In Colombia, dengue is a disease of great impact due to its morbidity and mortality, however, studies on the effects of the economic burden at the local level are scarce. Therefore, our study sought to describe the economic burden of dengue epidemics between 2010 and 2016 in the State of Meta, Colombia. A longitudinal study was performed using information from the records of the epidemiological information system (Sistema Nacional de Vigilancia en Salud Pública - SIVIGILA), and the indicator of disability-adjusted life years (DALYs) was determined as an estimator of the burden of dengue. To assess the economic impact, two assessment scenarios were considered (minimum range and maximum range), which allowed the estimate of the effects of the years of life lost (YLLs). Mortality cases presented heterogeneity in the age groups, mainly affecting groups under 15 years and over 65 years, with YLLs raging between 158.58 and 300.38. In total, 2010 showed the highest medical care costs of the study period, with USD 664,123 for women and USD 740,221 for men. In the epidemic years (2010, 2012-2015) between 91,072.3 and 184,175.1 DALYs were lost per million inhabitants, which generated social burden costs higher than the USD 669.6 million. In conclusion, dengue can be considered a disease of high cost at the local level, economically affecting the General Social Security System in Health and social welfare.
\end{abstract}

Dengue; Potential Years of Life Lost; Global Burden of Disease;

Health Care Costs

\author{
Correspondence \\ A. Vásquez-Trujillo \\ Escuela de Graduados, Universidad CES. \\ Calle 10 A, 22-04, Medellín, Antioquia 050021, Colombia. \\ vasquez.adolfo@uces.edu.co \\ ${ }^{1}$ Escuela de Graduados, Universidad CES, Medellín, Colombia.
}




\section{Introduction}

Dengue has become the main vector-borne disease in Colombia, since there were a total of 652,221 cases of dengue, 20,543 cases of severe dengue and 1,095 deaths caused by the virus between 2010 and 2016 (Pan American Health Organization. Reported cases of dengue fever in the Americas: 2016. http://www. paho.org/data/index.php/en/mnu-topics/indicadores-dengue-en/dengue-nacional-en/252-denguepais-ano-en.html, accessed on 06/Aug/2018), with an average incidence of 3,613.72 per million inhabitants, average general mortality rate of 6.12 per million inhabitants and a lethality of $6.97 \%$. Locally, in 2016, the State of Meta contributed with 2,575 (1.9\%) cases of dengue, $25(1.75 \%)$ cases of severe dengue and 7 fatal cases to national statistics 1 . These epidemiological characteristics show the effect on populations exposed in areas below 1,800 meters above sea level (MASL), added to the great difficulties related to their intervention, maintaining increasing epidemics since 2004, and serious economic effects, mainly in the General Social Security System in Health (GSSSH), which financed ambulatory, in-hospital care and drug supply of patients with dengue, reaching an approximate cost of more than USD 31 million in 20102 . The costs of medical care, including diagnostic tests and viral surveillance actions such as RT-PCR, viral isolation, antibody tests and histopathologies are another factor which total USD 537,088 3 , as well as vector control and epidemiological surveillance actions that reached USD 36 million 2. This situation makes dengue a primary problem in public health in Colombia.

Some of the tools that allow estimating the burden of a disease in a specific population are the indicators of years of life lost (YLLs), years of life lost due to disability (YDLs) and years of life adjusted for disability (DALYs), These indicators establish the time of life lost due to premature death, disability or permanent or transitory disability caused by a disease and its combination in a single indicator (DALYs). For their estimation, some parameters are considered, such as local life expectancy, estimated duration of disability and the condition's severity weight. These indicators allow to quantify the effect that a disease has had on society, established by the loss of productive years and the possibility of monetizing losses for society 4,5 .

Dengue has had a great social and economic impact in the world. An investigation conducted by Shepard et al. 6 reports an approximate DALYs of 20,223 per million inhabitants for dengue in the subAndean region of South America with approximate total costs of USD 538.6 million per year. Studies conducted in Brazil, showed that the cost of ambulatory dengue cases per person was USD 374, and USD 676 for hospitalized cases 7; in Colombia, these same estimates report a cost of USD 87.9 and USD 2,361, respectively 8 . The analysis of the cost of the dengue epidemic occurred in 1981 in Cuba by Kouri et al. 9 established that the approximate total cost of the epidemic was USD 103 million, with direct costs of about USD 84 million and indirect costs of USD 19 million. Studies conducted in Puerto Rico determined that the cost of the epidemic in 1977 ranged between USD 6 to USD 16 million, with direct costs (medical attention and control measures during epidemics) that ranged between USD 2.4 and USD 4.7 million, whereas indirect costs (labor days lost by sick workers and parents of sick children) ranged between USD 3.7 and USD 11 million 10. The DALYs indicator showed that the economic burden of dengue is substantial, comparable with other diseases considered epidemic ${ }^{11}$. For example, a study conducted in Thailand reports that the DALYs lost in the general population by dengue was 139 per million inhabitants with an estimated maximum of 284 per million inhabitants, while malaria was 502,000 DALYs per million inhabitants 12. Similar observations were reported by Meltzer 11, in which DALYs lost by dengue in Puerto Rico in a three-year study (1992-1994) was 933 per million inhabitants, with a maximum of 1,492 DALYs lost in 1994 as an epidemic period, which is equal to or greater than the DALYs lost caused by malaria (984 per million population) in the same period.

Although DALY manages to estimate social losses and costs due to an epidemic as an indicator of the economic burden of the disease 4,5,13, reports of the burden of dengue at the local level are scarce 10,14,15,16,17. This relevant information would allow prioritizing control and intervention measures in territorial entities with decentralized functions, as in Colombia 18. Given this epidemic, political and economic scenario, our study sought to describe the economic burden of dengue epidemics between 2010 and 2016, in the State of Meta, Colombia. 


\section{Materials and methods}

\section{Study site}

The State of Meta in Colombia was used as study population. This state has an area of $85,635 \mathrm{~km}^{2}$, it is

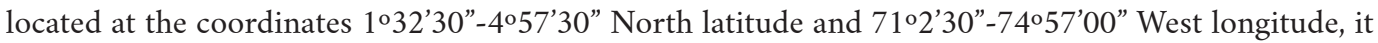
has an approximate population of 943,072 inhabitants in 29 municipalities with a concentration of $49.7 \%$ in the capital Villavicencio. The population has a $50 \%$ proportion between men and women with a higher concentration of people under 30 years old (56\%) 19. The State of Meta has diverse environmental conditions with altitude distribution between 125 and 4,000 MASL with a greater proportion of territory (93.5\%) less than 800 MASL, with average temperature of $26^{\circ} \mathrm{C}$ and annual precipitation of $4,538 \mathrm{~mm}$, which are favorable conditions for dengue transmission. Information taken from the Meta Govenment (Tierra de oportunidades. http://www.meta.gov.co/web/content/nuestro-departamento, accessed on 02/Feb/2019) and the Institute of Hydrology, Meteorology and Environmental Studies (Atlas climatológico de Colombia. http://www.ideam.gov.co/web/tiempo-y-clima/atlas, accessed on 02/Feb/2019).

\section{Type of study}

A retrospective longitudinal study was designed using as a source of data the reports of dengue cases, severe dengue, and dengue mortality under codes 210, 220 and 580 respectively, reported to the epidemiological information system (Sistema Nacional de Vigilancia en Salud Pública - SIVIGILA), conducted by the Office of epidemiological surveillance, from the Secretary of Health of the State of Meta, between 2010 and 2016. The data were classified according to the type of pathology, gender and age, the latter being divided into ranges of five years.

\section{Quantification of the burden of disease, mortality and morbidity}

To assess the economic burden of dengue, the DALYs was used 4,5,20 with modifications established by Rushby 13 regarding life expectancy; this indicator is based on the sum of the indicators YLLs and YLDs $($ DALYs $=$ YLLs + YLDs). The statistical tools available from World Health Organization (WHO) 21 were used to estimate the indicators.

\section{- YLLs}

The calculation was made based on the following formula:

$$
Y L L s(r, K)=\frac{K C e^{r a}}{(r+\beta)^{2}}\left(e^{-(r+\beta)(L+a)}(-(r+\beta)(L+a)-1)-e^{-(r+\beta) a}[-(r+\beta) a-1)+\frac{1-K}{r}\left(1-e^{-r L}\right)\right.
$$

where $K=$ modulation factor of the weighting age; $C=$ the constant correction with the weighting age; $r=$ discount rate; $\alpha=$ age of death; $\beta=$ parameter of the weighting age function; $L=$ national life expectancy.

\section{- YLDs}

The estimation was made by determining the disease incidence, prevalence, age of onset, duration, disability and disability weight (DW).

$$
Y L D s=D\left(\frac{C e^{r a}}{(r+\beta)^{2}}\left(e^{-(r+\beta)(L+a)}(-(r+\beta)(L+a)-1)-e^{-(r+\beta) a}(-(r+\beta) a-1)\right)+\frac{1-K}{r}\left(1-e^{-r L}\right)\right.
$$

where $D=$ the weight of the disability; $r$ = discount rate; $\alpha=$ age of onset of disability; $L=$ duration of disability. The parameters of the formula for the calculation of YLDs and YLLs were established in Table 1. To determine the costs of outpatient and inpatient care, we use as a basis the national values determined

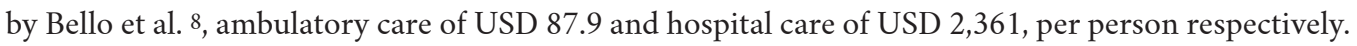



for dengue.

\begin{tabular}{cc}
\hline & Constant values \\
\hline YLLs & \\
$K$ & 1 \\
$C$ & 0.1658 \\
$R$ & 0.03 \\
$A$ & Age of death \\
$B$ & 0.04 \\
$L b$ & NA \\
$E$ & 2.77 (approximate) \\
YLDs & 1 \\
$K$ & 0.1658 \\
$C$ & 0.03 \\
$r$ & Age of disability \\
$a$ & 0.04 \\
$\beta$ & 10 \\
$L$ & 2.77 (approximate) \\
$e$ & 0.81 \\
$D W$ &
\end{tabular}

NA: not available.

Sources: Murray \& Lopez 4, Murray 5, Murray \& Lopez 20,

Beauté \& Vong 28, Luz et al. 38 and United Nations 44.

\section{Quantification of the economic impact of dengue}

To assess the economic impact of YLLs due to dengue in the State of Meta, the methodology proposed by Cavazos et al. 22, by Alvis et al. 23 was used, in which two valuation scenarios are considered; Minimum income range similar or inferior to a minimum legal wage effective for Colombia (SMLV) and maximum rank, income equal to or greater than 4 SMLV. It was calculated by multiplying the SMLV for each year of study by 12 months to determine the amount of income or minimum annual consumption.

To assess the economic impact of DALYs, the methodology proposed by Cropper \& Sahin 24 was used, using the following formula: (DALYs $\times$ YLLs index for Colombia $\times$ Gross Domestic Product per capita GDP); The YLLs index is based on the estimates for Colombia, determined in the Global Burden of Disease Study (GBD-2010) 25. The GDP was obtained from the Colombian National Administrative Department of Statistics (DANE; http://www.banrep.gov.co/es/pib). The economic value of YLLs and DALYs was expressed in international dollars per year, based on the reports of the Bank of the Republic of Colombia (http://www.banrep.gov.co/es/trm).

\section{Results}

The results of our study show the epidemiological impact of dengue in the State of Meta (Table 2). During the studied period, 58 deaths were recorded. The years 2010, 2013 and 2014 presented the highest mortality (9-12 cases) and the highest number of YLLs (219.92-300.38) due to dengue. However, the epidemic period was longer, starting in 2010, declining in 2011 (endemic period) and restarting in 2012 with a higher peak in 2014, followed by a decrease until reaching an endemic period in 2016 (Tables 3 and 4), showing a cyclic behavior. In general, the highest rates of YLLs due to dengue 
Epidemiological behavior of dengue in Colombia (2010-2016).

\begin{tabular}{|c|c|c|c|c|c|c|c|}
\hline & Dengue cases & $\begin{array}{c}\text { Dengue cases } \\
\text { (per } 1,000,000 \\
\text { habitants) }\end{array}$ & $\begin{array}{c}\text { Dengue hemorrhagic } \\
\text { cases }\end{array}$ & $\begin{array}{c}\text { Dengue } \\
\text { hemorrhagic cases } \\
\text { (per } 1,000,000 \\
\text { habitants) }\end{array}$ & Deaths & $\begin{array}{c}\text { Deaths (per } \\
1,000,000 \\
\text { habitants) }\end{array}$ & Lethality (\%) \\
\hline \multicolumn{8}{|l|}{2010} \\
\hline Women & 70,764 & $2,997.6$ & 4,692 & 198.8 & \multirow{2}{*}{221} & \multirow{2}{*}{9.36} & \multirow{2}{*}{2.3} \\
\hline Men & 76,662 & $3,247.3$ & 5,084 & 215.3 & & & \\
\hline \multicolumn{8}{|l|}{2011} \\
\hline Women & 17,047 & 722.1 & 756 & 32.0 & \multirow{2}{*}{43} & \multirow{2}{*}{1.82} & \multirow{2}{*}{3.3} \\
\hline Men & 12,344 & 522.9 & 547 & 23.2 & & & \\
\hline \multicolumn{8}{|l|}{2012} \\
\hline Women & 23,768 & 979.0 & 640 & 26.3 & \multirow{2}{*}{201} & \multirow{2}{*}{8.28} & \multirow{2}{*}{6.2} \\
\hline Men & 28,699 & $1,182.1$ & 772 & 31.8 & & & \\
\hline \multicolumn{8}{|l|}{2013} \\
\hline Women & 57,547 & $2,154.1$ & 1,463 & 54.8 & \multirow{2}{*}{183} & \multirow{2}{*}{6.85} & \multirow{2}{*}{5.8} \\
\hline Men & 64,894 & $2,429.1$ & 1,650 & 61.8 & & & \\
\hline \multicolumn{8}{|l|}{2014} \\
\hline Women & 49,517 & $1,853.6$ & 1,231 & 46.1 & \multirow{2}{*}{166} & \multirow{2}{*}{6.21} & \multirow{2}{*}{6.3} \\
\hline Men & 55,839 & $2,090.2$ & 1,388 & 52.0 & & & \\
\hline \multicolumn{8}{|l|}{2015} \\
\hline Women & 45,991 & $1,721.6$ & 688 & 25.7 & \multirow{2}{*}{155} & \multirow{2}{*}{5.80} & \multirow{2}{*}{10.9} \\
\hline Men & 49,032 & $1,835.4$ & 733 & 27.4 & & & \\
\hline \multicolumn{8}{|l|}{2016} \\
\hline Women & 50,159 & $1,784.1$ & 450 & 16.0 & \multirow{2}{*}{126} & \multirow{2}{*}{4.48} & \multirow{2}{*}{14.0} \\
\hline Men & 49,958 & $1,776.9$ & 449 & 16.0 & & & \\
\hline Total & 652,221 & & 20,543 & & 1,095 & & 5.33 \\
\hline Mean & $93,174.43$ & $3,613.72$ & $2,934.71$ & 118.17 & 156.43 & 6.12 & 6.97 \\
\hline
\end{tabular}

in Meta for men and women were presented in 2010 (294.1-211.3 per million inhabitants) and in 2014 (299.1-337.9 per million inhabitants).

Our analysis show that dengue is a disease of high social impact in Meta, whose total cost represents a decrease in the income of the GDP estimated in 2\% (2010), 0.46\% (2011), 1.68\% (2012), 3\% (2013) and $4 \%$ (2014), originated by the behavior of classic dengue cases, mainly in children under 15 years of age and cases of intra-hospital care (Tables 3 and 4). Maximum values of 3.5, 4.8 and 5.5 million dollars were estimated for the years 2010, 2013 and 2014 respectively (Table 3), and mainly due to the greater proportional loss (54\%) of women under 15 years of age ( 7 cases) and lower 4 years ( 8 cases). This population group is the most treated in the indicator of biological differences, with the lowest risks and the highest life expectancy 5 (Table 3 ).

The annual global costs of dengue in the State of Meta were exceptionally high in 2010 (USD $1,404,300)$ when compared with the other years studied. Although the number of cases for women and men were lower when compared with the period between 2012 and 2015, the number of total cases of hemorrhagic dengue (403) for 2010 was higher, resulting in a cost of USD 951,500 in intrahospital patient care (Table 4).

Dengue, along the seven years of follow-up, showed an apparent cyclic behavior, presenting similar values of DALYs and health care costs in 2011 and 2016 with a high peak in half of the two periods (2013), which describes a possible natural behavior of the disease and the effect on the burden of dengue in the upcoming years (Table 4). 
Table 3

Years of life lost (YLLs). State of Meta, Colombia.

\begin{tabular}{|c|c|c|c|c|c|c|c|c|c|c|c|c|c|c|c|}
\hline \multirow[t]{2}{*}{ Parameters } & \multicolumn{2}{|c|}{2010} & \multicolumn{2}{|c|}{2011} & \multicolumn{2}{|c|}{2012} & \multicolumn{2}{|c|}{2013} & \multicolumn{2}{|c|}{2014} & \multicolumn{2}{|c|}{2015} & \multicolumn{2}{|c|}{2016} & \multirow[t]{2}{*}{ Average } \\
\hline & Women & Men & Women & Men & Women & Men & Women & Men & Women & Men & Women & Men & Women & Men & \\
\hline Deaths & 5 & 4 & 4 & 3 & 3 & 4 & 3 & 6 & 5 & 7 & 1 & 6 & 3 & 4 & 8.3 \\
\hline $\begin{array}{l}\text { Deaths (per 1,000,000 } \\
\text { inhabitants) }\end{array}$ & 11.53 & 9.14 & 9.03 & 6.73 & 6.63 & 8.8 & 6.5 & 12.95 & 10.61 & 14.83 & 2.12 & 12.71 & 6.37 & 8.48 & 9 \\
\hline Average age & 21.6 & 44.5 & 29.5 & 20.3 & 16.7 & 41.8 & 22.7 & 20.2 & 18.3 & 32.6 & 2 & 41.8 & 43.7 & 34.5 & 27.6 \\
\hline Median age & 8 & 48 & 32 & 6 & 9 & 43 & 4 & 9 & 7 & 36 & 2 & 44 & 51 & 30 & 23.4 \\
\hline Minimum age & 3 & 4 & 7 & 3 & 6 & 5 & 3 & 4 & 4 & 1 & 2 & 2 & 4 & 26 & 5.2 \\
\hline Maximum age & 82 & 79 & 48 & 52 & 35 & 76 & 61 & 73 & 52 & 81 & 2 & 82 & 76 & 52 & 60.8 \\
\hline Q1 & 4 & 10 & 11 & 3 & 6 & 13 & 3 & 6 & 4 & 2 & NA & 9 & 4 & 27 & 7.7 \\
\hline Q3 & 47 & 76 & 46 & 52 & 35 & 70 & 61 & 33 & 31 & 57 & NA & 71 & 76 & 47 & 54 \\
\hline $0-4$ years & 2 & 1 & 0 & 1 & 0 & 0 & 2 & 1 & 2 & 3 & 1 & 1 & 1 & 0 & $15 * \star \star$ \\
\hline 5-14 years & 2 & 0 & 1 & 1 & 2 & 1 & 0 & 3 & 2 & 0 & 0 & 1 & 0 & 0 & $13 * \star \star$ \\
\hline $15-29$ years & 0 & 1 & 1 & 0 & 0 & 0 & 0 & 1 & 0 & 0 & 0 & 1 & 0 & 2 & $6 * \star \star$ \\
\hline 30-44 years & 0 & 0 & 2 & 0 & 1 & 1 & 0 & 0 & 0 & 1 & 0 & 0 & 0 & 1 & $6 * \star \star$ \\
\hline $45-59$ years & 0 & 0 & 0 & 1 & 0 & 1 & 0 & 0 & 1 & 2 & 0 & 0 & 1 & 1 & $7 * \star \star$ \\
\hline $60-69$ years & 0 & 1 & 0 & 0 & 0 & 0 & 1 & 0 & 0 & 0 & 0 & 2 & 0 & 0 & $4 * \star \star$ \\
\hline 70-79 years & 0 & 1 & 0 & 0 & 0 & 1 & 0 & 1 & 0 & 0 & 0 & 0 & 1 & 0 & $4 * \star \star$ \\
\hline $80+$ years & 1 & 0 & 0 & 0 & 0 & 0 & 0 & 0 & 0 & 1 & 0 & 1 & 0 & 0 & $3 * \star \star$ \\
\hline Total deceased & 5 & 4 & 4 & 3 & 3 & 4 & 3 & 6 & 5 & 7 & 1 & 6 & 3 & 4 & $58 * \star \star$ \\
\hline YLLS & 127.4 & 92.4 & 104.4 & 78.9 & 84.85 & 83.42 & 76.52 & 156.1 & 140.9 & 159.5 & 30.4 & 118.1 & 60.3 & 98.2 & 100.8 \\
\hline YLLs $\times 10^{6}$ inhabitants & 294.1 & 211.3 & 235.8 & 177 & 187.6 & 183.5 & 165.8 & 337.1 & 299.1 & 337.9 & 64.5 & 250.3 & 208.2 & 128 & 220 \\
\hline Minimum ceiling * & 415.1 & 301 & 363.1 & 274.5 & 320.9 & 315.5 & 289.6 & 591.1 & 520.8 & 589.3 & 85.5 & 332.5 & 163.4 & 266.2 & 344.9 \\
\hline Maximum ceiling ** & 2.075 & 1.505 & 1.815 & 1.372 & 1.604 & 1.577 & 1.448 & 2.955 & 2.6 & 2.95 & 0.43 & 1.66 & 0.82 & 1.33 & 1.7 \\
\hline Total minimum * & \multicolumn{2}{|c|}{716.07} & \multicolumn{2}{|c|}{637.63} & \multicolumn{2}{|c|}{636.45} & \multicolumn{2}{|c|}{880.68} & \multicolumn{2}{|c|}{1110.22} & \multicolumn{2}{|c|}{418.07} & \multicolumn{2}{|c|}{429.68} & 689.8 \\
\hline Total maximum ** & \multicolumn{2}{|c|}{3.58} & \multicolumn{2}{|c|}{3.188} & \multicolumn{2}{|c|}{3.182} & \multicolumn{2}{|c|}{4.403} & \multicolumn{2}{|c|}{5.55} & \multicolumn{2}{|c|}{2.09} & \multicolumn{2}{|c|}{2.15} & 3.4 \\
\hline
\end{tabular}

NA: not avalailable.

* Estimated cost expressed in USD thousands;

** Estimated cost expressed in USD millions;

*** Total deaths accumulated in the period 2010-2016.

The DALYs indicator for all years showed general values higher than 25,909.7 per million inhabitants (Table 5), mainly due to premature mortality and the number of cases in the age group under 25 years, which exceeds 50\% of the cases. All indicators showed a downward trend in the years of 2015 and 2016, possibly due to the emergence of the chikungunya virus in 2015 and Zika virus in 2016, which caused major epidemics in the municipality of Villavicencio, reaching 1,196 and 2,607 of notified cases, respectively 1 . 
Table 4

Estimating the cost of inpatient and outpatient cases of dengue. State of Meta, Colombia.

\begin{tabular}{|c|c|c|c|c|c|c|c|c|c|c|c|c|c|c|c|}
\hline & \multicolumn{2}{|c|}{2010} & \multicolumn{2}{|c|}{2011} & \multicolumn{2}{|c|}{2012} & \multicolumn{2}{|c|}{2013} & \multicolumn{2}{|c|}{2014} & \multicolumn{2}{|c|}{2015} & \multicolumn{2}{|c|}{2016} & \multirow[t]{2}{*}{ Total } \\
\hline & Women & Men & Women & Men & Women & Men & Women & Men & Women & Men & Women & Men & Women & Men & \\
\hline \multicolumn{16}{|l|}{ Dengue cases } \\
\hline \multicolumn{16}{|l|}{ Age groups (years) } \\
\hline $0-4$ & 259 & 336 & 167 & 207 & 378 & 417 & 452 & 467 & 244 & 256 & 197 & 216 & 144 & 195 & 3,935 \\
\hline $5-14$ & 616 & 598 & 363 & 383 & 860 & 972 & 1,409 & 1,436 & 807 & 772 & 677 & 693 & 231 & 239 & 10,056 \\
\hline $15-29$ & 688 & 961 & 300 & 463 & 669 & 893 & 1,036 & 1,258 & 641 & 757 & 866 & 993 & 335 & 418 & 10,278 \\
\hline $30-44$ & 363 & 571 & 189 & 258 & 406 & 572 & 619 & 744 & 348 & 485 & 616 & 583 & 276 & 337 & 6,367 \\
\hline $45-59$ & 216 & 265 & 104 & 157 & 241 & 282 & 373 & 418 & 209 & 289 & 362 & 367 & 181 & 167 & 3,631 \\
\hline $60-69$ & 60 & 83 & 47 & 44 & 88 & 108 & 120 & 138 & 76 & 82 & 131 & 124 & 48 & 61 & 1,210 \\
\hline $70-79$ & 42 & 44 & 27 & 43 & 48 & 69 & 68 & 86 & 30 & 46 & 91 & 89 & 54 & 39 & 776 \\
\hline $80+$ & 20 & 30 & 23 & 21 & 20 & 35 & 34 & 27 & 16 & 18 & 42 & 58 & 24 & 29 & 397 \\
\hline Total cases & 2,264 & 2,888 & 1,220 & 1,576 & 2,710 & 3,348 & 4,111 & 4,574 & 2,371 & 2,705 & 2,982 & 3,123 & 1,293 & 1,485 & 36,650 \\
\hline \multicolumn{16}{|l|}{$\begin{array}{l}\text { Dengue hemorrhagic } \\
\text { cases }\end{array}$} \\
\hline \multicolumn{16}{|l|}{ Age groups (years) } \\
\hline $0-4$ & 33 & 29 & 4 & 3 & 1 & 1 & 3 & 3 & 2 & 3 & 2 & 1 & 2 & 3 & 90 \\
\hline $5-14$ & 80 & 70 & 16 & 6 & 3 & 8 & 8 & 10 & 13 & 6 & 7 & 8 & 1 & 1 & 237 \\
\hline $15-29$ & 37 & 50 & 7 & 7 & 2 & 1 & 10 & 3 & 4 & 4 & 1 & 4 & 2 & 9 & 141 \\
\hline $30-44$ & 26 & 29 & 5 & 5 & 3 & 4 & 4 & 2 & 1 & 5 & 2 & 1 & 0 & 3 & 90 \\
\hline $45-59$ & 12 & 14 & 3 & 4 & 1 & 2 & 0 & 1 & 1 & 3 & 1 & 3 & 1 & 5 & 51 \\
\hline $60-69$ & 2 & 8 & 2 & 5 & 0 & 1 & 1 & 0 & 2 & 1 & 1 & 3 & 0 & 0 & 26 \\
\hline 70-79 & 6 & 3 & 2 & 2 & 0 & 1 & 0 & 1 & 2 & 1 & 0 & 2 & 0 & 0 & 20 \\
\hline $80+$ & 1 & 3 & 0 & 0 & 0 & 0 & 0 & 0 & 0 & 1 & 1 & 0 & 0 & 1 & 7 \\
\hline Total cases & 197 & 206 & 39 & 32 & 10 & 18 & 26 & 20 & 25 & 24 & 15 & 22 & 6 & 22 & 662 \\
\hline Cost of outpatient * & 199 & 253.8 & 107.2 & 138.5 & 238.2 & 294.3 & 361.4 & 402.1 & 208.4 & 237.8 & 262.1 & 274.5 & 113.7 & 130.5 & \\
\hline Cost of inpatient * & 465.1 & 486.4 & 92.1 & 75.6 & 23.6 & 42.9 & 61.4 & 47.2 & 56.7 & 59.0 & 35.4 & 51.9 & 14.2 & 51.9 & \\
\hline Total cost of healthcare * & 664.1 & 740.2 & 199.3 & 214.1 & 261.8 & 336.8 & 422.7 & 449.3 & 265.1 & 296.8 & 297.5 & 326.5 & 127.8 & 182.5 & \\
\hline
\end{tabular}

* Estimated cost expressed in USD thousands. 
Table 5

Years of life lost due to disability (YLDs) and disability-adjusted life years (DALYs) indicators. State of Meta, Colombia.

\begin{tabular}{|c|c|c|c|c|c|c|}
\hline & YLDs & $\begin{array}{c}\text { YLDs (per } \\
1,000,000 \text { habitants) }\end{array}$ & DALYs & $\begin{array}{c}\text { DALYs (per } 1,000,000 \\
\text { habitants) }\end{array}$ & $\begin{array}{l}\text { Total DALYs (per } \\
1,000,000 \text { habitants) }\end{array}$ & Estimated cost * \\
\hline \multicolumn{7}{|l|}{2010} \\
\hline Women & $31,420.7$ & $72,487.3$ & $31,548.2$ & $72,781.4$ & \multirow{2}{*}{$91,072.3$} & 266.3 \\
\hline Men & $47,676.1$ & $108,985.0$ & $47,768.6$ & $109,196.3$ & & 403.3 \\
\hline \multicolumn{7}{|l|}{2011} \\
\hline Women & $8,786.0$ & $19,842.8$ & $8,890.4$ & $20,078.6$ & \multirow{2}{*}{$25,909.7$} & 79.1 \\
\hline Men & $14,059.3$ & $31,521.6$ & $14,138.2$ & $31,698.6$ & & 125.7 \\
\hline \multicolumn{7}{|l|}{2012} \\
\hline Women & $37,150.4$ & $82,154.8$ & $37,235.3$ & $82,342.5$ & \multirow{2}{*}{$100,895.4$} & 340.6 \\
\hline Men & $54,173.8$ & $119,166.7$ & $54,257.2$ & $11,350.2$ & & 496.3 \\
\hline \multicolumn{7}{|l|}{2013} \\
\hline Women & $77,194.0$ & $167,217.2$ & $77,270.5$ & $119,350.2$ & \multirow{2}{*}{$184,175.1$} & 732.8 \\
\hline Men & $92,911.5$ & $200,572.4$ & $93,067.7$ & $200,909.5$ & & 882.6 \\
\hline \multicolumn{7}{|l|}{2014} \\
\hline Women & $59,376.2$ & $108,563.6$ & $59,517.1$ & $108,721.4$ & \multirow{2}{*}{103,619} & 582.5 \\
\hline Men & $38,043.7$ & $133,574.3$ & $38,203.1$ & $133,912.2$ & & 373.9 \\
\hline \multicolumn{7}{|l|}{2015} \\
\hline Women & $60,344.6$ & $128,081.8$ & $60,375.0$ & $128,146.3$ & \multirow{2}{*}{$114,664.4$} & 616.0 \\
\hline Men & $47,643.8$ & $100,954.9$ & $47,761.9$ & $101,205.2$ & & 487.3 \\
\hline \multicolumn{7}{|l|}{2016} \\
\hline Women & $60,344.6$ & $128,081.8$ & $60,404.9$ & $128,209.8$ & \multirow{2}{*}{$76,817.6$} & 607.4 \\
\hline Men & $11,941.4$ & $25,303.3$ & $12,039.7$ & $25,511.5$ & & 121.1 \\
\hline
\end{tabular}

* Estimated cost expressed in USD millions.

\section{Discussion}

Estimating the burden of dengue at the local level enables a better decision-making regarding political, economic and socio-environmental resolutions to establish control strategies $4,5,6$. Our study provides a longitudinal perspective of dengue loading for seven years, found different epidemiological patterns by identifying an initial epidemic period (2010), followed by an endemic period (2011), which continues with a prolonged epidemic period (2012-2015) and ends in a new endemic period (2016) (Tables 3 and 4). This apparent cyclical behavior at the local level is comparable to the results obtained by Castrillón et al. 26 at the national level, in which epidemic periods of three or four consecutive years are evident and consequent of multiple factors.

Locally, there are factors that hypothetically explain the complex multidimensional process in which the cyclical behavior observed for dengue develops in our investigation. In its socio-environmental dimension, we observe the existence of factors such as displacement, demographic increase in municipal headwaters and illegal urbanizations with inadequate water supply and sewerage systems 26 between 2010 and 2014. In its climatic dimension, the phenomenon of "La Niña" and "El Niño" in Colombia starting with La Niña between 2010 and 2012, and the phenomenon of El Niño between 2013 and 2015 with a transitional period to the phenomenon of La Niña in 2016 (Instituto de Hidrología, Meteorología y Estudios Ambientales. Fenómenos El Niño y La Niña. http://institucional.ideam.gov.co/jsp/2925, accessed on 30/Aug/2018) are conditions related to the increase of up to $12 \%$ the costs produced by dengue 27,28. And finally, in the immunological dimension, in which the existence of susceptible population generates epidemic processes 29 , as the process generated by circulation of serotypes 1,3 and 4 in 2012, and the introduction of serotype 2 in 201330 in the State of Meta. 
The estimate of the social burden and costs for dengue considers the number of cases reported, depending on the severity of the clinical presentation 17 , which is a common process when compared with that observed in the local health system, in which the notification rates of symptomatic dengue are higher when the cases present alarming symptoms or require hospitalization, coinciding with the process observed in other endemic countries 6 . In our study, the evaluation of the cost of healthcare was based on data estimated by Bello et al. 8 , and the number of outpatient and hospitalized cases was obtained from the notifications of the epidemiological surveillance office, thus only the estimated value of the direct costs of dengue in Meta is expressed (Table 4), assuming for these costs the medical attention, laboratory, medicines and hospital supplies; without considering other direct costs assumed by the same patients or their relatives with the purchase of medicines and home care 28 , labor costs of health personnel 16, or indirect costs such as school and work absenteeism 11 , which could influence $64.8 \%$ of the total cost of dengue 15,16,31; possibly increasing the total costs of dengue in the State of Meta.

A possible limitation of our study was the incorporation of national estimated values for the cost of outpatient and inpatient medical care. However, the estimated value per person ranged between USD 509 in 2010, USD 291 in 2011 and a range of USD 196 to 219 for the years 2012-2016, according to the effect obtained by the cost of in-hospital management of a greater number of hemorrhagic dengue cases in 2010 and 2011. These estimates are comparable to those obtained in bibliographic reviews, in which the cost of outpatient treatment in the Andean countries was in the range of USD 155-351, and intra-hospital treatment in a range of USD 392-1,298 6, or the global cost estimates per patient of USD 414 in 2011 32. This is an effect possibly attributable to factors such as the inexperience in the medical management of patients, under socialization and adherence to the guide to comprehensive clinical care of dengue patients, which was introduced in 201033.

Another limitation of our study is the non-use of expansion factors, commonly used to adjust the underreporting of symptomatic dengue cases 14,34,35; however, it is noteworthy that routine surveillance systems are not designed to exhaustively detect all cases 36 . Therefore, our data provide approximate information on the economic burden and annual costs of medical care of dengue in the State of Meta (Tables 3, 4 and 5), which shows an alarming situation due to the economic effects caused by the GSSSH and social aspects in the population.

The application of different disability scores has been a factor related to the variability in the estimation of the economic-social burden and the DALYs indicator of dengue in different studies. The first parameters were estimated in the disability weight index of 0.172-0.211 with 30 days of disability (equivalent to uncomplicated malaria) 20; however, the values increased by 0.471 due to different clinical forms and cases with severe symptoms 37 . In our study, we decided to use disability values of 0.81 with an average duration of 10 days for hemorrhagic dengue and 4.5 days for classic dengue due to clinical variability, disability of non-hospitalized patients and hospitalized patients; punctuation parameters and duration of disability according to studies done in Latin America, the Caribbean and other tropical zones $11,28,38$.

DALYs is an indicator of the time lived with disability and of the years lost due to premature death, considering the age, sex, incidence, duration of the disease and adjustment for age, for which it considers the loss of health in the short and long term, calculating the gap between the present health situation of the population with an ideal age of disease-free old age 4,5,13,20. Our annual estimates of dengue DALYs are higher, greater than $184,175.1$ per million inhabitants, considering studies conducted at the national level with DALYs of 1,198.73 per million inhabitants in the years 2010-2012 2. However, this may result from the comparison between the incidence of total dengue of the State of Meta (3,466 cases per million inhabitants) and Colombia (2,737 cases per million inhabitants). DALYs estimated in the State of Rio de Janeiro, Brazil, which accounted for 1,532 per million inhabitants, show results similar to our study, since the authors found that the local estimates are greater than the national ones when comparing results of the state and the country, which accounted for 338.2 per million inhabitants 38 . Other study performed in Puerto Rico, in 1996 (933 per million inhabitants) 11, in Cambodia, in 2006, 2007 and 2008 (400, 1,166 and 243 per million inhabitants, respectively) 28, and in the Americas in general, in 2007 (median of 72,772 DALYs lost), show results of DALYs comparable to those obtained in Meta between 2010 and 2016, maintaining the proportion of the difference between local and national numbers.

Despite the limitations, our methodology allows us to demonstrate the magnitude of dengue epidemics based on another point of view, working as an input to establish indicators of endemic dengue, 
epidemic monitoring or the introduction of new arboviruses in the State of Meta. This proposal shows how dengue, as a transient disease, has a disease burden higher than acute respiratory infections (ARI) or acute diarrheal disease (ADD) in Meta during 2010, with 9,910 DALYs lost per million inhabitants for ARI and 842 DALYs lost per million inhabitants for ADD 39, whereas our investigation obtained 91,072.3 DALYs per million inhabitants for dengue. This type of comparison shows how the disease burden of dengue for Meta, despite the maintenance of the proportions by size of the population, can be as important or similar to diseases as tuberculosis (7,170 DALYs per million inhabitants) and HIV/AIDS (11,840 DALYs per million inhabitants) in Latin America 40, and confirms how dengue has become a disease of considerable impact.

Finally, the analysis of the tendency to decrease cases of dengue corresponding to the years 2015 and 2016, which shows a significant decrease in the costs of medical care and DALY mainly in women, can be hypothetically explained by the emergence of chikungunya and zika viruses in 2014 and $2015^{41,42}$, mainly due to the cross-reactive immunological effects that can generate a protective effect on the population, evidenced in recent studies in Recife, Pernambuco State, Brazil, in which the emergence of chikungunya displaced the cases of zika and dengue in the city 43 , accompanied by a decrease in the population susceptible to dengue by presenting circulation of the four serotypes in the State of Meta 30.

The presence of dengue virus and the emergence of chikungunya and Zika virus shows that viral transmission by mosquitoes (Aedes aegypti) continues in the State of Meta, economically affecting the health system (approximately USD 4,784,517 in the observed period), and directly or indirectly affecting the population mostly poor and with suboptimal access to care, which assume a large part of the cost of the disease 11,28. Thus, the incorporation of surveillance tools to identify infections in populations should be well implemented in different geographical scenarios, employed in vulnerable populations, such as children, adolescents and pregnant women, to avoid the development of complications due to dengue and its consequences in YLLs and DALYs, with high burden and social cost. For this reason, research should be prioritized to identify interventions with a more immediate impact, and not suffer the natural epidemiological development of dengue at the local level.

In conclusion, our study shows that dengue is a disease with high economic burden in the state of Meta (USD 204,819,006 in 2011 - USD 1,615,456,216 in 2013), which is comparable to diseases such as HIV/AIDS considering premature deaths up to $300 \mathrm{YLL}$, mostly affecting a greater proportion of groups under 25 years of age, with 170,337 DALY lost per year, mainly caused by hemorrhagic cases and long periods of hospitalization and convalescence of the disease at home. Finally, our study emphasizes the apparent association between the behavior of epidemics and socio-environmental conditions, global climatic phenomena and the immunological conditions of susceptibility of the population to dengue virus infection.

\section{Contributors}

A. Vásquez-Trujillo participated in the study conception and design, acquisition of data, analysis and interpretation of data, and agreement to be accountable for all aspects of the work in ensuring that questions related to the accuracy or integrity of any part of the work are appropriately investigated and resolved. D. Cardona-Arango, A. M. Segura-Cardona and G. J. Parra-Henao revised the article and approved the version to be published.

\section{Additional informations}

ORCID: Adolfo Vásquez-Trujillo (0000-00023671-9223); Doris Cardona-Arango (0000-00034338-588X); Angela María Segura-Cardona (00000002-0010-1413); Gabriel Jaime Parra-Henao (0000-0003-4535-6521).

\section{Acknowledgments}

The authors would like to thank the Health Secretariat of the State of Meta, Colombia, specially to Omar Ramírez Gómez Coordinator of Epidemiological Surveillance, for providing the necessary information to develop the investigation. 


\section{References}

1. Oficina de Vigilancia Epidemiológica, Secretaria de Salud del Meta. Boletín Epidemiológico semana 52 de 2016. Villavicencio: Secretaria de Salud del Meta; 2016.

2. Rodríguez RC, Carrasquilla G, Porras A, Galera-Gelvez K, Yescas JGL, Rueda-Gallardo JA. The burden of dengue and the financial cost to Colombia, 2010-2012. Am J Trop Med Hyg 2016; 94:1065-72.

3. Instituto Nacional de Salud. Rol del Laboratorio Nacional de Referencia en la epidemia de dengue, Colombia 2010. In: Simposio de Virologia 2010. https://www.ins.gov.co/buscador -eventos/Informacin\%20de\%20laboratorio/ Rol\%20del\%20LNR\%20en\%20epidemia\%20 dengue\%20Colombia\%20\%202010.pdf (accessed on 06/Aug/2018)

4. Murray CJL, Lopez AD. Quantifying disability: data, methods and results. Bull World Health Organ 1994; 72:481-94.

5. Murray CJL. Quantifying the burden of disease: the technical basis for disability-adjusted life years. Bull World Health Organ 1994; 72:429-45.

6. Shepard DS, Coudeville L, Halasa YA, Zambrano B, Dayan GH. Economic impact of dengue illness in the Americas. Am J Trop Med Hyg 2011; 84:200-7.

7. Suaya JA, Shepard DS, Siqueira JB, Martelli CT, Lum LCS, Tan LH, et al. Cost of dengue cases in eight countries in the Americas and asia: a prospective study. Am J Trop Med Hyg 2009; 80:846-55.

8. Bello S, Díaz S, Malagón-Rojas J, Romero M, Salazar V. Medición del impacto económico del dengue en Colombia: una aproximación a los costos médicos directos en el periodo 20002010. Biomédica 2011; 31 Suppl 3:110-3.

9. Kouri G, Guzmán G, Bravo J, Triana C. Dengue haemorrhagic fever/dengue shock syndrome: lessons from the Cuban epidemic, 1981. Bull World Health Organ 1986; 67:375-80.

10. von Allmen SD, Lopez-Correa RH, Woodall JP, Morens DM, Chiriboga J, Casta-Velez A. Epidemic dengue fever in Puerto Rico, 1977: a cost analysis. Am J Trop Med Hyg 1979; 28:1040-4.

11. Meltzer MI, Rigau-Pérez JG, Clark GG, Reiter P, Gubler DJ. Using disability-adjusted life years to assess the economic impact of dengue in Puerto Rico: 1984-1994. Am J Trop Med Hyg 1998; 59:265-71.

12. Anderson KB, Chunsuttiwat S, Nisalak A, Mammen MP, Libraty DH, Rothman AL, et al. Burden of symptomatic dengue infection in children at primary school in Thailand: a prospective study. Lancet 2007; 369:1452-9.

13. Rushby JF. Calculating and presenting disability adjusted life years (DALYs) in cost-effectiveness analysis. Health Policy Plann 2001; $16: 326-31$
14. Dechant EJ, Rigau-Pérez JG. Hospitalizations for suspected dengue in Puerto Rico, 19911995: estimation by capture-recapture methods. The Puerto Rico Association of Epidemiologists. Am J Trop Med Hyg 1999; 61:574-8.

15. Valdés LG, Vila Mizhrahi J, María Guzmán DG. Impacto económico de la epidemia de dengue 2 en Santiago de Cuba, 1997. Rev Cuba Med Trop 2002; 54:220-7.

16. Añez G, Balza R, Valero N, Larreal Y. Impacto económico del dengue y del dengue hemorrágico en el Estado de Zulia, Venezuela, 19972003. Rev Panam Salud Pública 2006; 19:31420.

17. Duarte HHP, França EB. Qualidade dos dados da vigilância epidemiológica da dengue em Belo Horizonte, MG. Rev Saúde Pública 2006; 40:134-42.

18. Congreso de Colombia. Ley 715 , de diciembre 21 de 2001. Por la cual se dictan normas orgánicas en materia de recursos y competencias de conformidad con los artículos 151, 288, 356 y 357 (Acto Legislativo 01 de 2001) de la Constitución Política y se dictan otras disposiciones para organizar la prestación de los servicios de educación y salud, entre otros. https://www. mineducacion.gov.co/1621/articles-86098_ archivo_pdf.pdf (accessed on 07/Aug/2018).

19. Secretaria de Salud del Meta. Análisis de situación de salud con el modelo de los determinantes sociales de salud 2014. Meta: Secretaria de Salud del Meta; 2014.

20. Murray L, Lopez A. The global burden of disease: a comprehensive assessment of mortality and disability from diseases, injuries, and risk factors in 1990 and projected to 2020. Geneva: World Health Organization; 1996.

21. World Health Organization. Health statistics and information systems: national tools, 2018. http://www.who.int/healthinfo/global_bur den_disease/tools_national/en/ (accessed on 10/Mar/2018).

22. Cavazos-Ortega N, Del Rio Zolezzi A. Años de vida potencial perdidos: Su utilidad en el análisis de la mortalidad en México. Salud Pública Méx 1988; 31:610-24.

23. Alvis-Guzmán N, Alvis-Estrada L. Costos económicos de la mortalidad evitable en Cartagena, Colombia, 2000-2005. Rev Salud Pública 2009; 11:970-8.

24. Cropper M, Sahin S. Valuing mortality and morbidity in the context of disaster risks. Washington DC: Wold Bank; 2009. (Policy Research Working Paper, 4832).

25. Murray CJL, Ezzati M, Flaxman AD, Lim S, Lozano R, Michaud C, et al. GBD 2010: a multi-investigator collaboration for global comparative descriptive epidemiology. Lancet 2012; 380:2055-8. 
26. Castrillón JC, Castaño JC, Urcuqui S. Dengue en Colombia: diez años de evolución. Rev Chil Infectol 2015; 32:142-9.

27. Markandya A, Chiabai A. Valuing climate change impacts on human health: empirical evidence from the literature. Int J Environ Res Public Health 2009; 6:759-86.

28. Beauté J, Vong S. Cost and disease burden of dengue in Cambodia. BMC Public Health 2010; 10:521.

29. Focks D, Daniels E, Haile DG, Keesling JE. A simulation model of the epidemiology of urban dengue fever: literature analysis, model development, preliminary validation, and samples of simulation results. Am J Trop Med Hyg 1995; 53:489-506.

30. Romero-Vega L. Informe final del evento dengue, año 2012. https://www.ins.gov.co/busca dor-eventos/Informesdeevento/Dengue 2012. pdf (accessed on 15/Jul/2019).

31. Armien B, Suaya JA, Quiroz E, Sah BK, Bayard V, Marchena L, et al. Clinical characteristics and national economic cost of the 2005 dengue epidemic in Panama. Am J Trop Med Hyg 2008; 79:364-71.

32. Castro MC, Wilson ME, Bloom DE. Disease and economic burdens of dengue. Lancet Infect Dis 2017; 17:e70-8.

33. Ministerio de la Protección Social; Instituto Nacional de Salud; Organización Panamericana de la Salud. Guía de atención clínica integral del paciente con dengue. Bogotá: Ministerio de la Protección Social; 2010.

34. Vong S, Goyet S, Ly S, Ngan C, Huy R, Duong $\mathrm{V}$, et al. Under-recognition and reporting of dengue in Cambodia: a capture-recapture analysis of the National Dengue Surveillance System. Epidemiol Infect 2012; 140:491-9.

35. Shepard DS, Undurraga EA, Lees RS, Halasa Y, Lum LCS, Ng CW. Use of multiple data sources to estimate the economic cost of dengue illness in Malaysia. Am J Trop Med Hyg 2012; 87:796-805.
36. Gubler DJ. How effectively is epidemiological surveillance used for dengue programme planning and epidemic response? Dengue Bull 2002; 26:96-106.

37. Mathers CD, Ezzati M, Lopez AD. Measuring the burden of neglected tropical diseases: the global burden of disease framework. PLoS Negl Trop Dis 2007; 1:e114.

38. Luz PM, Grinsztejn B, Galvani AP. Disability adjusted life years lost to dengue in Brazil. Trop Med Int Health 2009; 14:237-46.

39. Calderón-Ramírez V. Desigualdad en carga de enfermedad por Infección respiratoria aguda (IRA) y enfermedad diarreica aguda (EDA) en menores de 5 años, Colombia 2010. Bogotá: Universidad Nacional de Colombia; 2016.

40. Murray CJL, Vos T, Lozano R, Naghavi M, Flaxman AD, Michaud C, et al. Disability-adjusted life years (DALYs) for 291 diseases and injuries in 21 regions, 1990-2010: a systematic analysis for the Global Burden of Disease Study 2010. Lancet 2012; 380:2197-223.

41. Dirección de Vigilancia y Análisis del Riesgo en Salud Pública, Instituto Nacional de Salud. Boletín Epidemiológico Semanal 2014; (53). http://www.ins.gov.co/buscador-eventos/Bo letinEpidemiologico/2014_Boletin_epidemio logico_semana_53.pdf.

42. Dirección de Vigilancia y Análisis del Riesgo en Salud Pública, Instituto Nacional de Salud. Boletín Epidemiológico Semanal 2015; (52). http://www.ins.gov.co/buscador-eventos/Bo letinEpidemiologico/2015_Boletin_epidemio logico_Semana_52.pdf.

43. Magalhães T, Braga C, Cordeiro MT, Oliveira ALS, Castanha PMS, Maciel APR, et al. Zika virus displacement by a chikungunya outbreak in Recife, Brazil. PLoS Negl Trop Dis 2017; 11:e0006055.

44. United Nations. Model life tables for developing countries. New York: United Nations; 1982. 


\section{Resumen}

En Colombia, el dengue es una enfermedad de gran impacto, debido a la morbimortalidad. No obstante, se ha estudiado poco sobre los efectos de la carga económica de la enfermedad en el nivel local. Por ello, el estudio tiene como objetivo describir la carga de las epidemias de dengue entre 2010 y 2016 en el estado de Meta, Colombia. Se realizó un estudio longitudinal, utilizando datos del sistema de información epidemiológica (Sistema Nacional de Vigilancia en Salud Pública - SIVIGILA). El indicador AVAIs (años de vida ajustados por incapacidad) se calculó como el estimador de la carga de dengue. Para evaluar el impacto económico, se utilizaron dos escenarios de evaluación (limites inferior y superior de la variación), lo que permitió estimar los efectos de los años de vida perdidos. La mortalidad mostró heterogeneidad entre los grupos de edad, afectando principalmente a los grupos con menos de 15 años y con más de 65 años, con pérdida de años de vida entre 158,58 y 300,38. El año 2010 registró los mayores gastos en cuidados médicos durante el período de estudio, con USD 664.123 para mujeres y USD 740.221 para hombres. Durante los años epidémicos, (2010 y 2012-2015), entre 91.072,3 y 184.175,1 AVAIs se perdieron por millón de habitantes, generando costes de carga social de más de USD 669,6 millones. El estudio concluye que el dengue puede ser considerado una enfermedad de coste elevado en el nivel local, afectando económicamente el Sistema General de Seguridad Social y el bienestar social de la población.

Dengue; Años Potenciales de Vida Perdidos; Carga Global de Enfermedades; Costos de la Atención en Salud

\section{Resumo}

Na Colômbia, a dengue é uma doença de grande impacto, devido à morbimortalidade, porém há pouco estudados sobre os efeitos da carga econômica da doença em nível local. Portanto, o estudo teve como objetivo descrever a carga das epidemias de dengue entre 2010 e 2016 no Estado de Meta, Colômbia. Foi realizado um estudo longitudinal, utilizando dados do sistema de informações epidemiológicas (Sistema Nacional de Vigilancia en Salud Pública - SIVIGILA). O indicador AVAIs (anos de vida ajustados para incapacidade) foi calculado como estimador da carga de dengue. Para avaliar o impacto econômico, dois cenários de avaliação foram utilizados (limites inferior $e$ superior da variação), o que permitiu estimar os efeitos dos anos de vida perdidos. A mortalidade mostrou heterogeneidade entre os grupos etários, afetando principalmente os grupos com menos de 15 anos e com mais de 65 anos, com perda de anos de vida entre 158,58 e 300,38. O ano de 2010 registrou os maiores gastos em cuidados médicos durante o período de estudo, com USD 664.123 para mulheres e USD 740.221 para homens. Nos anos epidêmicos, (2010 e 2012-2015), entre 91.072,3 e 184.175,1 AVAIs foram perdidos por milhão de habitantes, gerando custos de carga social de mais de USD 669,6 milhões. O estudo conclui que a dengue pode ser considerada uma doença de custo elevado em nivel local, afetando economicamente o Sistema Geral de Seguridade Social e o bem-estar social da população.

Dengue; Anos Potenciais de Vida Perdidos; Carga Global de Doença; Custos de Cuidados de Saúde
Submitted on 19/Mar/2019

Final version resubmitted on $02 /$ Oct $/ 2019$

Approved on 19/Nov/2019 